\title{
SMOKING DURING PREGNANCY, DIET AND LEVELS OF SOME MICRONUTRIENTS IN ADOLESCENTS WITH PRIMARY HYPERTENSION
}

\author{
Kolarova - Yaneva ${ }^{1}$ N., M. Angelova ${ }^{2}$, V. Nedkova ${ }^{1}$, A. Bozhinova ${ }^{2}$, K. Gospodinov ${ }^{3}$ S. \\ Tisheva $^{3}$, M. Tzonzarova ${ }^{4}$ \\ 1. Department of Pediatrics, Medical University - Pleven, Bulgaria \\ n.i.yaneva@hotmail.com \\ 2. Department of Chemistry and Biochemistry \& Biophysics and Physics, \\ Medical University - Pleven, Bulgaria \\ 3. Department of Cardiology , Pulmonology, Endocrinology, \\ Medical University - Pleven, Bulgaria \\ 4. National Cardiology Hospital - Sofia, Bulgaria
}

\section{ABSTRACT}

Primary hypertension frequency in children is determined by cardiovascular risk factors such as obesity, smoking and inappropriate diet. The success of strategies for its prevention is dependent on a plurality of perinatal and postnatal risk factors.

\section{THE AIM}

of this study was to investigate the influence of potential risk factors like maternal smoking during pregnancy and the diet throughout the first year of the child for primary hypertension occurrence and the level of certain trace elements in children with primary hypertension.

\section{MATERIAL AND METHODS:}

The study was conducted among 61 students aged 10-17 years with hypertension and a control group of 20 normotensive children. Maternal smoking during pregnancy and the diet of the infant were determined and studied by conducting a survey. Spectrophotometric methods were used to determine the serum levels of the trace elements $\mathrm{Zn}, \mathrm{Cu}, \mathrm{Cr}$. The data was processed statistically using Statgraphics.

\section{RESULTS:}

We found that $47.5 \%$ of the mothers of children with hypertension had smoked during pregnancy. $80.4 \%$ of children with hypertension were formula fed and only $19.6 \%$ of them were breast-fed. Significantly lower levels of serum zinc $(9,90 \pm$ $1,63 \mu \mathrm{mol} / \mathrm{I}$ ) were found in $66.6 \%$ of the children with hypertension. Serum copper levels were statistically significantly lower in $50 \%$ of the children $(6,76 \pm 2,96 \mu \mathrm{mol} / \mathrm{I})$. All patients with hypertension had significantly lower chromium $(0,68 \pm$ $0,26 \mu \mathrm{mol} / \mathrm{I})$.

\section{CONCLUSION :}

Smoking mother during pregnancy and formula feeding during the first year of life can probably be considered risk factors for early hypertension manifestation. The status of trace elements $\mathrm{Zn}, \mathrm{Cu}, \mathrm{Cr}$ showed a deficit in children with hypertension. Given the role of these micronutrients in cholesterol metabolism, their low serum levels may lead to early, preclinical vascular changes.

\section{Indexing terms/Keywords}

primary hypertension; trace elements; adolescents

\section{Academic Discipline And Sub-Disciplines}

Medicine

\section{TYPE (METHOD/APPROACH)}

Research

\section{Council for Innovative Research}

\section{Peer Review Research Publishing System}

\section{Journal: Journal of Social Science Research}

Vol .4, No.3

Jssreditor.cir@gmail.com

www.jssronline.com 


\section{INTRODUCTION}

Primary hypertension frequency in children is determined by cardiovascular risk factors such as obesity, smoking and inappropriate diet.

The success of strategies for its prevention is dependent on a plurality of perinatal and postnatal risk factors.

Many biological and epidemiological studies have shown the beneficial effects of breastfeeding regarding chronic diseases in adulthood - high blood pressure, diabetes, obesity $(1,2)$.

There is literature data that indicates that maternal smoking throughout pregnancy (PDB) affects arterial, endothelial function, the thickness of the carotid artery and the early onset of atherosclerosis. $(3,4,5,6)$.

Lately the main scientific focus is on disorders of mineral metabolism because such changes may have an important role in the pathogenesis of cardiovascular diseases.

A low intake of vitamins and minerals is widespread and most likely due to the excessive consumption of energy-rich foods. ( 7).

\section{THE AIM}

of this study was to investigate the influence of potential risk factors like maternal smoking during pregnancy and the diet throughout the first year of the child for primary hypertension occurrence and the level of certain trace elements in children with primary hypertension.

\section{MATERIAL AND METHODS:}

The study was conducted among 61 students aged 10-17 years with hypertension and a control group of 20 normotensive children. Arterial hypertension is diagnosed according to ESH/ESC guideline.

Maternal smoking during pregnancy and the diet of the infant were determined and studied by conducting a survey. Blood sample (5ml.) was taken, after signing informed consent, for quantity measurement of levels of

mictonutrients.Spectrophotometric methods were used to determine the serum levels of the trace elements $\mathrm{Zn}, \mathrm{Cu}, \mathrm{Cr}$. The data was processed statistically using Statgraphics.

\section{RESULTS AND DISCUSION:}

We found that $47.5 \%$ of the mothers of children with hypertension had smoked during pregnancy ( Fig 1).

$$
\text { w smoking during pregnancy }{ }^{-} \text {no data } " \text { non smokers }
$$
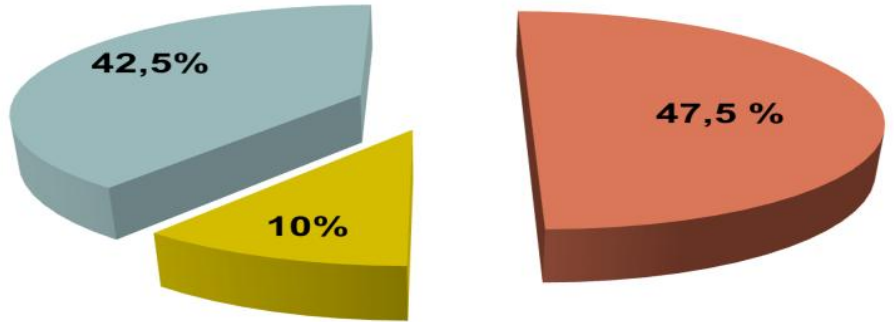

Fig 1: Mother smoking during pregnancy

$\mathbf{8 0 . 4 \%}$ of children with hypertension were formula fed and only $19.6 \%$ of them were breast-fed ( Fig 2

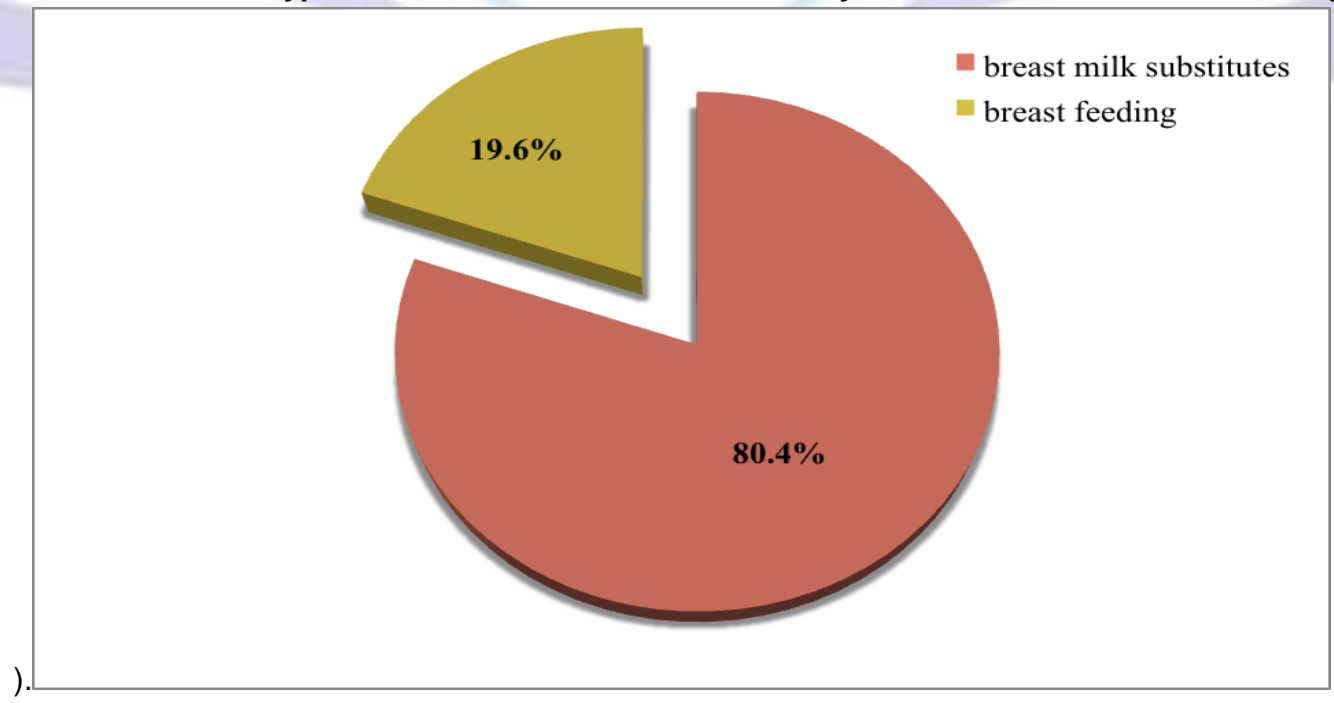

Fig 2: Infant feeding 
Significantly lower levels of serum zinc $(9,90 \pm 1,63 \mu \mathrm{mol} / \mathrm{I})$ were found in $66.6 \%$ of the children with hypertension. Serum copper levels were statistically significantly lower in $50 \%$ of the children $(6,76 \pm 2,96 \mu \mathrm{mol} / \mathrm{l})$. All patients with hypertension had significantly lower chromium $(0,68 \pm 0,26 \mu \mathrm{mol} / \mathrm{I})$ (Fig 3).

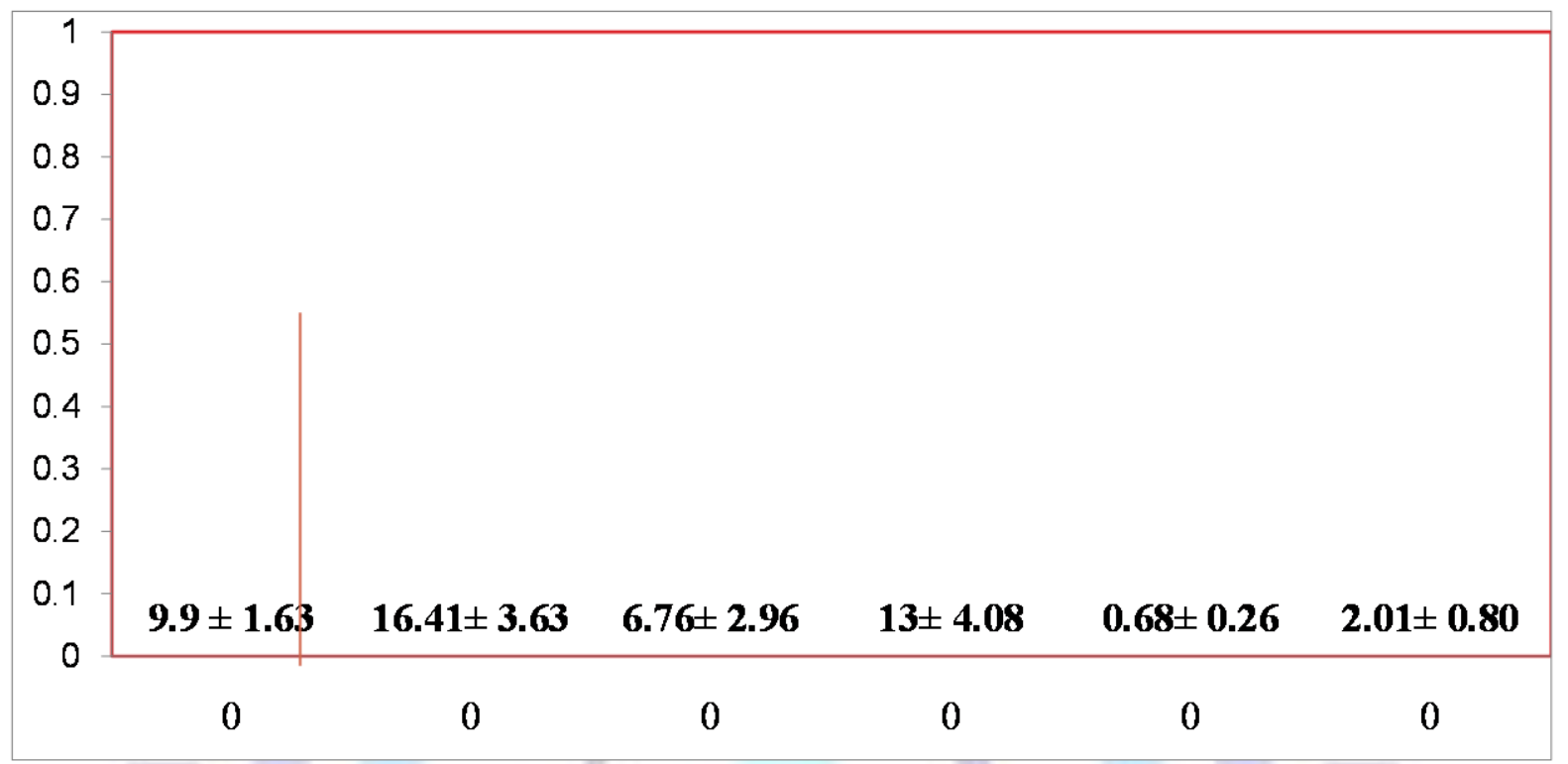

Fig 3: Levels of serum micronutrients $(\mathrm{Zn}, \mathrm{Cu}, \mathrm{Cr})$

The tobacco smoke leads to a variety of effects in the vessel wall (8, 9). There is some certain evidence that young people exposed to passive smoking have significantly altered cardiac parameters (10-12). Children whose mothers smoked throughout pregnancy have higher systolic blood pressure values, and these values correlate with the number of cigarettes smoked by the mother (13).

The positive effects of breastfeeding on blood pressure values can be explained by : a reduced sodium content in milk (14) , the high content of polyunsaturated fatty acids - which have an important role on coronary endothelial system. Due to their high fat and protein, BMS (breast milk substitutes) may lead to increased secretion of insulin -like growth factor type 1, stimulation of adipocytes and subsequently to becoming overweight .

Many studies indicate that only long-term breastfeeding affects childhood obesity

$(1,15,16)$. Therefore, the promotion of breastfeeding can have both short-term and long-term positive health effects of children.

The study data of low serum zinc and copper values is similar to the data gathered by several other authors.

Tomat $A L$, et all showed that serum zinc deficiency is the cause of reduced activity of nitric oxide with subsequent of blood pressure

Research done by Tubek et al 2007 , Lap Lambert et al 2011 found lower - intake and - low serum zinc concentrations in
children with hypertension
$(18$,
19).

Disturbances in endothelial - dependent arterial relaxation are associated with copper deficiency (20).Shortage of zinc and copper can be associated with an increased risk of hypertension ( 21,22). Chromium reduces insulin resistance, which could have beneficial effects on high blood pressure (23). Correlation between low intake of chromium and increased values of blood pressure in adults was found recently. Therefore chromium supplementation in order to reduce blood pressure and to regulate the glucose metabolism is recommended $(24)$.

\section{CONCLUSION:}

Smoking mother during pregnancy and formula feeding during the first year of life can probably be considered risk factors for early hypertension manifestation. The status of trace elements $\mathrm{Zn}, \mathrm{Cu}, \mathrm{Cr}$ showed a deficit in children with hypertension. Given the role of these micronutrients in cholesterol metabolism, their low serum levels may lead to early, preclinical vascular changes. 


\section{REFERENCES}

[1] Roya Kelishadi, Sanam Farajian. 2014. The protective effects of breastfeeding on chronic non-communicable diseases in adulthood: A review of evidence. Adv Biomed Res, 3:3

[2] Debbie A. Lawlor, Jake M. Najman, Jonathan Sterne, Gail M. Williams, Shah Ebrahim, Dm, George Davey Smith 2004. Associations of Parental, Birth, and Early Life Characteristics With Systolic Blood Pressure at 5 Years of Age, Circulation 110: 24 17-2423

[3] Geelhoed JJ, El Marroun H, Verburg BO. 2011. Maternal smoking during pregnancy, fetal arterial resistance adaptations and cardiovascular function in childhood. BJOG;118(6):755-762

[4] Milei J, Ottaviani G, Lavezzi AM, Grana DR, Stella I, Matturri L. 2008. Perinatal and infant early atherosclerotic coronary lesions. Can J Cardiol24(2):137-14

[5] Layla L. de Jonge, Holly R. Harris, Janet W. Rich-Edwards, Walter C. Willett, Michele R. Forman, Vincent W.V. Jaddoe, Karin B. Michels. 2013. Parental Smoking in Pregnancy and the Risks of Adult-Onset Hypertension. Hypertension. 61: 494-500

[6] Dunbar A, Gotsis W, Frishman W. 2013. Second-hand tobacco smoke and cardiovascular disease risk: an epidemiological review. Cardiol Rev. 21(2):94-100

[7] Bruce N. Ames, Low micronutrient intake may accelerate the degenerative diseases of aging through allocation of scarce micronutrients by triage. 2006. Nutrition and Metabolism Center, Children's Hospital of Oakland Research Institute

[8] A. D. Flouris, C. I. Vardavas, G. S. Metsios, A. M. Tsatsakis, and Y. Koutedakis. 2010. Biological evidence for the acute health effects of secondhand smoke exposure, American Journal of Physiology, vol. 298, no. 1, pp. L3-L12.

[9] T. Raupach, K. Schäfer, S. Konstantinides, and S. Andreas.2006 .Secondhand smoke as an acute threat for the cardiovascular system: a change in paradigm. European Heart Journal, vol. 27, no. 4, pp. 386-392.

[10] A. D. Flouris, G. S. Metsios, and G. S. Metsios.2009. Acute and short-term effects of secondhand smoke on lung function and cytokine production, American Journal of Respiratory and Critical Care Medicine, vol. 179, no. 11, pp. 1029-1033

[11] A. D. Flouris, G. S. Metsios, A. Z. Jamurtas, and Y. Koutedakis.2008.Sexual dimorphism in the acute effects of secondhand smoke on thyroid hormone secretion, inflammatory markers and vascular function, American Journal of Physiology, vol. 294, no. 2, pp. E456-E462

[12] G. S. Metsios, A. D. Flouris, and A. D. Flouris.2007. Brief report: a brief exposure to moderate passive smoke increases metabolism and thyroid hormone secretion. Journal of Clinical Endocrinology and Metabolism, vol. 92, no. 1, pp. 208-211.

[13] Giacomo D. Simonetti, Rainer Schwertz, Martin Klett, Georg F. Hoffmann, Franz Schaefer. 2011. Determinants of Blood Pressure in Preschool Children : The Role of Parental Smoking. Circulation.123:292-298

[14] Samuel J. Fomon, 2001. Infant Feeding in the 20th Century: Formula and Beikost J J. Nutr. February 1, vol. 131 no. 2 409S-420S

[15] Owen CG, Whincup PH, Kaye CG, Martin RM, Smith GD, Cook D. 2008. Does initial breastfeeding lead to lower blood cholesterol in adult life? A quantitative review of the evidence. Am J Clin Nutr. 88:305-14 